\title{
PENGEMBANGAN MODUL PEMBELAJARAN KIMIA MATERI POKOK STRUKTUR ATOMBERBASIS INKUIRI TERBIMBING
}

\author{
Tri Saslina ${ }^{1}$, Mawardi ${ }^{2}$, Latisma $\mathrm{Dj}^{3}$ \\ ${ }^{1}$ Institut Agama Islam Negeri Kerinci, Jln. KaptenMuradi Sungai Liuk, Sungai Penuh, Indonesia \\ ${ }^{2}$ UniversitasNegeri Padang, Jl. Prof. Dr. Hamka, AirTawar Barat, Padang, Indonesia \\ saslinatri@yahoo.com
}

\begin{abstract}
Type of research is the research and the development (R \& D) to develop chemistry learning modules for the main material atom structural based guided inquiry and to explain about validity, practicality and effectiveness of the resulting module. Expansion model used is 4-D model. The development begins with analyze the front end, the students, the tasks and the concepts analysis. It's be continued by designing chemistry learning modules based guided inquiry. Than the module developed through development stage such as validation and revision based on validator comments to get valid learning module to be tested in the field. The valid learning module was tested to the students to explain the module practicality and effectiveness. The result of data analysis show that learning module was valid with the average value of kappa moment 0,73 . Practicality module was shown by the result of data analysis of questionnaire for teacher response with kappa moment value 0,85 and the questionnaire for student response with kappa moment 0,80 . Based on the result of this study, it can be concluded that learning module was valid and practical to used in chemistry learning. The effectiveness test showed that the average value of students' understanding was 82,31 .
\end{abstract}

Keywords: Chemistry Learning Modules, Atom Structural, Guided Inquiry

\begin{abstract}
Abstrak
Jenis penelitian ini adalah penelitian dan pengembangan (research and development) yang bertujuan untuk mengembangkan modul pembelajaran kimia pada materi pokok struktur atom berbasis inkuiri terbimbing dan mengungkapkan validitas, praktikalitas, dan efektifitas dari modul yang dihasilkan. Model pengembangan yang digunakan adalah model pengembangan 4-D. Pengembangan diawali dengan melakukan analisis ujung depan, siswa, tugas, dan analisis konsep, dan dilanjutkan dengan perancangan modul pembelajaran kimia berbasis inkuiri terbimbing. Setelah selesai dirancang, modul pembelajaran melalui tahapan pengembangan berupa validasi dan revisi dari validator untuk mendapatkan modul pembelajaran yang valid untuk dilakukan ujicoba di lapangan. Modul pembelajaran yang telah valid diujicoba pada siswa untuk mengungkap kepraktisan dan keefektifannya. Data dianalisis secara statistik deskriptif dan hasil analisis data menunjukkan bahwa modul pembelajaran valid dengan skor rata-rata momen kappa sebesar 0,73. Praktikalitas modul ditunjukkan oleh hasil analisis data angket respon guru dengan momen kappa sebesar 0,85 dan angket respon siswa dengan momen kappa sebesar 0,80. Berdasarkan hasil penelitian dapat disimpulkan bahwa modul pembelajaran yang dikembangkan sangat valid dan praktis untuk digunakan dalam proses pembelajaran kimia. Hasil uji efektifitas modul menunjukkan bahwa berupa nilai rata-rata pemahaman siswa sebesar 82,31.
\end{abstract}

Kata kunci:Modul Pembelajaran Kimia, Struktur Atom, Inkuiri Terbimbing

Kemajuan suatu bangsa sangat ditentukan oleh kualitas sumber daya manusia. Salah satu cara untuk meningkatkan kualitas sumber daya manusia tersebut adalah melalui pembelajaran yang terjadi di dunia pendidikan. Pembelajaran adalah proses interaksi peserta didik dengan guru dan sumber belajar pada suatu lingkungan belajar. Proses pembelajaran perlu direncanakan, dilaksanakan, dinilai, dan diawasi agar terlaksana secara efektif dan efisien. Siswa akan mudah memahamai konsep yang abstrak jika siswa dibimbing untuk membangun pengetahuannya dengan cara penemuan konsep sendiri dan menempatkan siswa sebagai subjek belajar. Setiap siswa dalam proses pembelajarn memiliki kecepatan dan kemampuan yang berbeda-beda dalam menerima materi pembelajaran. Selain itu keterbatasan 
waktu di kelas juga membuat siswa tidak optimal dalam mencapai tujuan pembelajaran. Oleh karena itu dibutuhkan suatu bahan ajar yang dapat membuat siswa belajar secara mandiri di samping pembelajaran di dalam kelas (Nurhidayah, Irwandi \& Saridewi, 2015). Semakin besar keterlibatan siswa dalam kegiatan belajar, maka semakin besar baginya untuk mengalami proses belajar. Hal ini sesuai dengan tuntutan kurikulum yang digunakan saat ini yaitu Kurikulum 2013 revisi 2017 (Alfirahmi, 2018).

Inkuiri terbimbing merupakan suatu strategi yang dapat membangun pemahaman siswa berdasarkan pengetahuan awal, mengikuti siklus pembelajaran berupa orientasi, eksplorasi, pembentukan konsep, aplikasi, dan penutup, berdiskusi dan berinteraksi dengan orang lain (Hanson, 2006). Proses pembelajaran berbasis inkuiri terbimbing ini menggunakan sistem belajar kelompok, dan menggunakan bahan ajar berorientasi inkuiri terbimbing yang didasarkan pada siklus belajar eksplorasi, pembentukan konsep, dan aplikasi. Dalam belajar kelompok, siswa bekerjasama membangun pemahaman dan pengetahuan, sehingga siswa belajar lebih banyak, mengerti lebih banyak dan mengingat lebih banyak apabila mereka bekerjasama (Hanson, 2006). Dengan melibatkan siswa dalam proses pembelajaran dapat meningkatkan motivasi dan kinerja serta memberikan kesempatan kepada mereka untuk mengembangkan komunikasi dan keterampilan berpikir.

Pada tahap eksplorasi siswa memiliki kesempatan melakukan pengamatan dan menganalisis data atau informasi yang berupa gambar, grafik, tabel data, atau rumus. Pada tahap pembentukan konsep siswa diberikan pertanyaan-pertanyaan yang memaksa siswa untuk berfikir kritis karena mereka terlibat dalam eksplorasi. Pertanyaan-pertanyaan ini disebut key questions (pertanyaan kunci) yang memandu siswa dalam eksplorasi. Pertanyaan-pertanyaan tersebut dapat membantu mengarahkan siswa ke informasi yag dituju, menuntun siswa menemukan hubungan dan kesimpulan yang sesuai, dan membantu siswa membangun pemahaman tentang konsep yang sedang dipelajari. Dan pada tahap aplikasi siswa diberi latihan. Latihan memberikan siswa kesempatan untuk membangun kepercayaan diri dalam situasi yang sederhana (Hanson, 2005).

Dalam pembelajaran inkuiri terbimbing, guru bertindak sebagai fasilitator dan motivator yang memberikan bantuan sesuai dengan kebutuhan siswa. Guru memfasilitasi siswa dengan menyediakan modul untuk pembelajaran, memotivasi siswa untuk belajar dan menciptakan lingkungan belajar yang mendukung agar siswa dapat belajar dengan nyaman dan belajar menjadi bermakna.

Dahar (2011) menyatakan bahwa Bruner menganggap bahwa belajar penemuan sesuai dengan pencarian pengetahuan secara aktif oleh manusia dan dengan sendirinya memberikan hasil yang paling baik. Berusaha sendiri untuk mencari pemecahan masalah serta pengetahuan yang menyertainya, menghasilkan pengetahuan yang benar-benar bermakna. Pengetahuan yang diperoleh dengan belajar penemuan menunjukkan beberapa kebaikan. Pertama, pengetahuan itu bertahan lama atau lama diingat atau lebih mudah diingat bila dibandingkan dengan pengetahuan yang dipelajari dengan cara-cara lain. Kedua, hasil belajar penemuan mempunyai efek transfer yang lebih baik daripada hasil belajar lainnya. 
Ketiga, secara menyeluruh belajar penemuan meningkatkan penalaran siswa dan kemampuan untuk berpikir secara bebas.

Menurut Depdiknas (2008) modul adalah seperangkat bahan ajar yang disajikan secara sistematis sehingga penggunaannya dapat belajar dengan atau tanpa seorang fasilitator/ guru. Suryosubroto (1983) menyatakan bahwa dalam proses belajar mengajar, penggunaan modul dapat merangsang situasi belajar yang lebih mengaktifkan siswa untuk memecahkan masalah-masalah dibawah pengawasan dan bimbingan guru. Penelitian sebelumnya telah berhasil mengembangkan modul pembelajaran kimia materi struktur atom berbasis Al-qur'an (Badlisyah, 2018), modul pembelajaran hidrolisis garam berbasis model inkuiri terbimbing (Isworini, Sunarno \& Saputro, 2015); dan modul berbasis inkuri terbimbing (guided inquiry) pada pokok bahasan reaksi oksidasi reduksi (Mawantia, Fajaroh \& Afandy, 2013) yang valid, praktis dan efektif meningkatkan hasil belajar siswa pada materi tertentu. Tujuan penelitian ini adalah mengembangkan modul pembelajaran kimia berbasis inkuiri terbimbing pada pokok bahasan struktur atom berbasis inkuiri terbimbing yang memenuhi kriteria validitas dan praktikalitas serta efektif dalam meningkatkan hasil belajar kimia khususnya pada pokok bahasan struktur atom.

\section{METODE}

Penelitian yang dilakukan ini termasuk dalam kategori penelitian dan pengembangan (Research and Development), yang menghasilkan suatu produk baru dalam pembelajaran yaitu modul pembelajaran kimia untuk mengajarkan Struktur atom pada siswa kelas X SMA. Model pengembangan yang digunakan dalam penelitian ini adalah model 4D. Menurut Thiagarajan, dkk dalam Trianto (2010) model ini terdiri dari 4 tahap yaitu pendefinisian (Define), perancangan (Design), pengembangan (Develop), dan penyebaran (Desseminate).

Pada tahapan ini dilakukan modifikasi modul yang dihasilkan pada tahap perancangan, sebelum menjadi produk akhir yang siap untuk digunakan. Dalam tahap ini dilakukan tiga langkah yaitu validasi (penilaian) produk, revisi, uji coba dan tahap penyebaran. Tahap ini merupakan tahap penggunaan modul yang telah dikembangkan pada skala yang lebih luas misalnya di kelas lain, di sekolah lain, oleh guru yang lain. Tahap penyebaran ini dilakukan untuk mempromosikan produk pengembangan agar bisa diterima pengguna, baik individu, suatu kelompok atau sistem. Namun karena keterbatasan penulis untuk melakukan promosi dan keterbatasan penulis untuk bekerjasama dengan penerbit untuk melakukan promosi yang lebih luas dan para praktisi pendidikan, maka penelitian ini hanya terbatas pada tahap pengembangan.

Produk yang sudah dihasilkan diujicobakan pada siswa kelas X SMAN 1 Kerinci. Jenis data yang dikumpulkan dalam penelitian ini adalah (a) validitas produk, data validitas berupa hasil validasi produk yang dikembangkan berupa modul pembelajaran oleh validator yang ahli dibidangnya; (b) praktikalitas produk, data praktikalitas diperoleh dari hasil uji coba terbatas di lapangan menyangkut kepraktisan dan keterlaksanaan produk yang dikembangkan; dan (c) efektivitas, data efektivitas 
diperoleh berdasarkan hasil uji coba produk di lapangan menyangkut hasil belajar siswa menggunakan produk yang dikembangkan.

Instrumen yang digunakan dalam penelitian ini adalah (a) lembar validasi modul pembelajaran, yaitu berupa angket yang digunakan untuk menilai validitas isi dan validasi konstruk dari modul yang dihasilkan; (b) angket respon siswa dan respon guru terhadap modul yang digunakan selama proses pembelajaran berlangsung; dan (c) tes hasil belajar yang digunakan untuk menentukan persentase keberhasilan siswa setelah mengikuti pembelajaran menggunakan modul. Data tes hasil belajar selanjutnya digunakan untuk melihat efektivitas modul yang dikembangkan dari segi hasil belajar siswa. Data hasil penelitian dianalisis dengan statistik deskriptif untuk mendapatkan angka rata-rata dan persentase. Teknik analisis data untuk masing-masing data hasil penelitian dapat diuraikan sebagai berikut:

\section{Analisis Validitas Isi dan Validitas Konstruk}

Teknik analisis validitas isi, desain, praktikalitas dan efektifitas didasarkan kepada categorical judgments yang dimodifikasi dari Boslaugh \&Watters (2008). Pada categorical judgments, validator dan guru diberikan pernyataan untuk kemudian memberikan penilaian terhadap masing-masing pernyataan tersebut. Lembar yang diberikan berupa angket dan pada bagian akhir diberikan kesempatan bagi validator maupun guru untuk memutuskan hasil dari penilaian yang telah diberikan. Penilaian validator dan guru terhadap masing-masing pernyataan dianalisis menggunakan formula Kappa Cohen (Boslaugh \& Watters, 2008) dimana pada akhir pengolahan diperoleh momen kappa.

$$
\text { Momen kappa }(k)=\frac{P o-P e}{1-P e}
$$

\section{Analisis Kepraktisan}

Sama halnya dengan analisis lembar validasi isi dan konstruk, maka lembar praktikalitas (angket respon guru dan angket respon siswa) juga dianalisis menggunakan formula Kappa Cohen.

\section{Analisis Efektivitas}

Analisis data efektivitas diperoleh dari lembar penilaian hasil belajar siswa.Analisis tes hasil belajar didasarkan pada data hasil belajar siswa pada ranah kognitif. Modul pembelajaran yang dikembangkan dikatakan efektif jika pemahaman siswa berada di atas Kriteria Ketuntasan Minimal (KKM) sekolah uji coba yaitu 70. Analisis pemahaman dapat dicari menggunakan persamaan:

$$
\text { Pemahaman siswa }=\frac{\text { jumlah jawaban benar }}{\text { jumlah total pertanyaan }} \times 100
$$

\section{HASIL}

\section{Hasil Tahap Pendefenisian (Define)}

Tahap pendefinisian dilakukan untuk melihat gambaran bagaimana kondisi di lapangan yang berkaitan dengan proses pembelajaran kimia. Langkah-langkah yang dilakukan pada tahap ini meliputi 4 langkah, yaitu analisis ujung depan, analisis siswa, analisis tugas, dan analisis konsep. 


\section{Analisis Ujung Depan}

Pada tahap ini dilakukan analisis terhadap kurikulum, karena proses pembelajaran yang dilaksanakan berpedoman pada kurikulum yaitu kurikulum KTSP. Pelaksanaan pembelajaran yang terdapat dalam KTSP menyatakan bahwa dalam proses pembelajaran menuntut siswa yang harus aktif dalam membangun pengetahuan dan guru berperan sebagai fasilitator. Untuk mewujudkan tujuan pembelajaran kimia yang dituntut oleh KTSP, maka kegiatan pembelajaran haruslah berpusat pada siswa. Salah satu pendekatan yang berpusat pada siswa adalah pembelajaran berbasis inkuiri terbimbing. Pada proses pembelajaran berbasis inkuiri terbimbing ini guru berfungsi sebagai motivator yang memberi ransangan supaya siswa aktif dan bergairah untuk berfikir. Modul yang dikembangkan untuk materi pokok struktur atom termasuk materi pokok bidang studi kimia yang dipelajari siswa kelas X SMA pada semester 1. Materi struktur atom ini tercakup dalam Standar Kompetensi (SK) 1. Sedangkan Kompetensi Dasar yang harus tercapai setelah siswa mempelajari materi ini adalah KD 1.1. Kompetensi Dasar 1.1 yaitu Memahami struktur atom berdasarkan Teori atom Bohr, sifat-sifat unsur, massa atom relatif, dan sifat-sifat periodik unsur dalam tabel periodik serta menyadari keteraturannya, melalui pemahaman konfigurasi elektron.

\section{Analisis Siswa}

Analisis siswa merupakan telaah karakteristik siswa yang meliputi tingkat perkembangan kognitif, kemampuan, latar belakang pengetahuan, dan meliputi usia, motivasi terhadap mata pelajaran, kemampuan akan latar belakang sosial budaya siswa. Dalam penelitian ini, yang menjadi subjek uji coba adalah siswa SMA kelas X semester I yang usianya berkisar 16-17 tahun, maka menurut teori Piaget siswa pada kelompok usia seperti itu berada dalam tahap operasional formal atau mereka telah mampu untuk berfikir abstrak. Jadi pada tahap ini siswa sudah mampu menyelasaikan masalah dengan cara yang lebih baik dan komplek dari pada anak yang masih berada dalam tahap operasional konkrit.

\section{Analisis Tugas}

Dalam analisis tugas kegiatan yang dilakukan adalah menganalisis Standar Kompetensi dan Kompetensi Dasar yang akan dikembangkan modul pembelajarannya. Berdasarkan hasil identifikasi SK dan KD yang terdapat dalam silabus, dijabarkan beberapa indikator. Materi struktur atom yang tecakup dalam SK 1 serta KD 1.1 dapat dijabarkan menjadi beberapa indikator.

\section{Analisis Konsep}

Analisis konsep dilakukan untuk mengidentifikasi dan menyusun secara sistematis konsepkonsep struktur atom yang diperlukan.

\section{Hasil Tahap Perancangan (Design) \\ Penyusunan Tes}

Penyusunan tes merupakan langkah awal yang menghubungkan antara tahap define dan tahap design. Tes disusun berdasarkan indikator pencapaian kompetensi dasar dan indikator kemampuan pemecahan masalah yang termuat dalam kisi-kisi penyusunan tes (Rochmad, 2011). Bentuk tes hasil 
belajar terdiri dari 35 soal pilihan ganda. Tes yang dibuat diuji validitas, reliabilitas, daya beda, dan indeks kesukarannya.

\section{Pemilihan Bahan Ajar}

Langkah ini meliputi pemilihan bahan ajar yang sesuai untuk menyajikan materi pembelajaran. Proses pemilihan bahan ajar disesuaikan dengan hasil analisis ujung depan, analisis tugas dan analisis konsep serta karakteristik siswa. Berdasarkan analisis tersebut maka dipilih bahan ajar yang akan dikembangkan yaitu modul berbasis inkuiri terbimbing.

\section{Pemilihan Format}

Pada tahap ini dilakukan pemilihan format modul yang akan dibuat. Format yang digunakan disesuaikan dengan indikator yang sudah dirumuskan. Format yang dimaksud dalam hal ini adalah tampilan, sistematika penyajian materi, dan isi modul. Sistematika penyajian materi sesuai dengan siklus pembelajaran berbasis inkuiri terbimbing dan isi dari modul sesuai dengan indikator.

\section{Rancangan Awal}

Rancangan awal adalah rancangan seluruh kegiatan yang harus dilakukan sebelum uji coba dilaksanakan. Berdasarkan langkah-langkah merancang modul berbasis inkuiri terbimbing maka rancangan dari modul pembelajaran berbasis inkuiri terbimbing berisikan (1) judul materi berupa struktur atom; (2) petunjuk belajar penggunaan modul pembelajaran kimia berbasis inkuiri terbimbing; (3) standar kompetensi yaitu memahami struktur atom; (4) Kompetensi Dasar 1.1 yaitu memahami struktur atom berdasarkan teori atom Bohr, sifat-sifat unsur, massa atom relatif, dan sifat-sifat periodik unsur dalam tabel periodik serta menyadari keteraturannya, melalui pemahaman konfigurasi elektron; dan (5) aktivitas kimia, terdiri atas indikator yang dijabarkan dari hasil identifikasi Kompetensi Dasar 1.1;model, dapat berupa gambar, grafik, tabel data, dan satu atau lebih persamaan; pertanyaan kunci, yang dapat membantu mengarahkan siswa ke informasi yang dituju, menuntun siswa menemukan hubungan dan kesimpulan yang sesuai, dan membantu siswa membangun pemahaman tentang konsep yang sedang dipelajari; dan (d) latihan yang merupakan aplikasi dari konsep yang dipelajari.

\section{Hasil Tahap Pengembangan (Develop)}

Tahap pengembangan bertujuan untuk menghasilkan modul pembelajaran berbasis inkuiri terbimbing yang layak digunakan dalam pembelajaran kimia pada materi pokok struktur atom. Pada tahap initer diri dari tiga langkahya itu memvalidasi modul, menentukan praktikalitas dan menentukan efektifitas dari modul pembelajaran kimia berbasis inkuiri terbimbing yang sudah dikembangkan dalam proses pembelajaran di kelas. Modul pembelajaran berbasis inkuiri terbimbing yang dikembangkan haruslah valid. Modul pembelajaran dikatakan valid jika sesuai dengan materi pelajaran yang akan diajarkan. Validitas yang diukur dalam penelitian ini adalah validitas isi dan validitas konstruk.

Kevalidan modul pembelajaran berbasis inkuiri terbimbing yang dihasilkan dapat diketahui dengan validasi oleh validator. Dalam penelitian ini, yang ditunjuk sebagai validator untuk menilai 
modul pembelajaran adalah dua orang dosen dan satu orang guru kimia. Hasil validasi selanjutnya dianalisis untuk mengetahui validitas modul baik dari segi kelayakan isi, kelayakan konstruk, komponen kebahasaan dan komponen kegrafisan.

Berdasarkan data validasi kelayakan isi modul pembelajaran tampak 100\%, 75\%, dan 58,33\% pernyataan yang divalidasi oleh validator I, II, dan III telah memiliki validitas tinggi dan $0 \%, 25 \%$, dan $41,67 \%$ pernyataan yang divalidasi oleh validator I, II, dan III telah memiliki validitas sangat tinggi. Sehingga dapat disimpulkan, dari segi kelayakan isi, kesesuaian modul pembelajaran dengan kurikulum yang meliputi SK, KD, indikator memiliki kategori kevalidan tinggi.

Sedangkan dari segi kelayakan konstruksi modul yang dihasilkan sudah sistematis, karena modul adalah seperangkat bahan ajar yang disajikan secara sistematis sehingga dapat digunakan dalam kegiatan belajar mengajar (Depdiknas, 2008). Dapat dilihat dari data validasi kelayakan konstruksi modul pembelajaran pada tampak 100\%, 100\%, dan 50\% pernyataan yang divalidasi oleh validator I, II, dan III telah memiliki validitas tinggi dan $0 \%, 0 \%$, dan $50 \%$ pernyataan yang divalidasi oleh validator I, II, dan III telah memiliki validitas sangat tinggi.

Dari segi ketepatan penggunaan bahasa dalam modul pembelajaran memiliki kategori kevalidan tinggi dengan momen kappa 0,70. Dapat dilihat dari data validasi komponen kebahasaan modul pembelajaran pada tampak $100 \%, 100 \%$, dan $83,33 \%$ pernyataan yang divalidasi oleh validator I, II, dan III telah memiliki validitas tinggi dan $0 \%, 0 \%$, dan 16,67\% pernyataan yang divalidasi oleh validator I, II, dan III telah memiliki validitas sangat tinggi. Sedangkan dari segi kegrafisan pada tampak $100 \%, 100 \%$, dan $40 \%$ pernyataan yang divalidasi oleh validator I, II, dan III telah memiliki validitas tinggi dan $0 \%, 0 \%, 60 \%$ pernyataan yang divalidasi oleh validator I, II, dan III telah memiliki validitas sangat tinggi.

Tingkat kepraktisan modul pembelajaran berbasis inkuiri terbimbing yang dikembangkan dapat dilihat dari sejauh mana guru dan siswa dapat menggunakan modul pembelajaran tersebut selama proses pembelajaran di kelas. Untuk mengetahui apakah modul yang dibuat praktis digunakan atau tidak, dilakukan ujicoba pada siswa kelas X di SMA Negeri I Kerinci.

Praktikalitas modul dapat dilihat dari data hasil angket respon guru dan angket respon siswa yang diolah dengan rumus Kappa Cohen untuk memperoleh nilai kappa dan melihat praktikalitas modul tersebut. Praktikalitas modul ditunjukkan oleh hasil analisis data angket respon guru dengan momen kappa sebesar 0,85 dan angket respon siswa dengan momen kappa sebesar 0,80. Berdasarkan hasil penelitian dapat disimpulkan bahwa modul pembelajaran yang dikembangkan sangat praktis untuk digunakan dalam proses pembelajaran.

Efektifitas modul pembelajaran berkaitan dengan hasil belajaryang diperoleh siswa setelah mengikuti proses pembelajaran dengan menggunakan modulpembelajaranberbasisinkuiriterbimbing yang dikembangkan. Sesuai dengan pendapat Sudjana (2008) menyatakan bahwa kegiatan penilaian merupakan suatu tindakan atau kegiatan untuk melihat sejauh mana tujuan-tujuan pembelajaran telah dicapai atau dikuasai oleh siswa dalam bentuk hasil belajar yang diperlihatkannya setelah mengikuti 
proses belajar mengajar. Modul pembelajaran dikatakan efektif jika hasil tes yang diperoleh siswa sesuai dengan harapan yaitu nilai siswa dapat mencapai atau melampaui KKM yang ditetapkan sekolah. Nilai KKM untuk bidang studi kimia di SMA uji coba adalah 70 .

Soal tes yang diberikan untuk uji efektifitas berbentuk tes objektif sebanyak 25 butir soal.. Uji coba dilakukan pada 26 orang siswa. Berdasarkan data hasil belajar siswa dapat diketahui bahwa dari 26 orang siswa ujicoba, hanya 3 orang siswa yang memperoleh nilai tidak tuntas dalam tes yang diadakan. Namun secara keseluruhan rata-rata nilai yang diperoleh siswa ujicoba sudah cukup tinggi yaitu 82,31. Nilai ini sudah berada di atas nilai Kriteria Ketuntasan Minimal (KKM), dimana KKM untuk bidang studi kimia di sekolah ujicoba yaitu 70. Jadi secara keseluruhan modul pembelajaran yang dihasilkan sudah efektif untuk mengajarkan materi struktur atom pada siswa kelas X SMA.

Meski terdapat perbedaan pada pokok bahasan yang dikembangkan, hasil pengembangan modul tidak jauh berbeda dengan hasil pengembangan modul pada materi lain yang dikembangkan oleh Yerimadesi, Putra \& Ririyanti (2017) yaitu modul larutan penyangga berbasis discovery learning yang juga efektif meningkatkan hasil belajar siswa. Sehingga hasil pengembangan modul pada materi struktur atom dapat menjadi salah satu altenatif media pembelajaran yang bisa digunakan pada pokok bahasan tersebut disamping hasil pengembangan media pembelajaran lain seperti model e-book interaktif termodifikasi majalah Najihah (2014) dan modul pembelajaran kimia berbasis blog (Sari, Saputro \& Saputro, 2014).

\section{KESIMPULAN}

Berdasarkan hasil analisis data validasi dan hasil uji coba modul pembelajaran berbasis inkuiri terbimbing yang dikembangkan, dapat diambil beberapa kesimpulan sebagai berikut (1) Modul pembelajaran berbasis inkuiri terbimbing pada materi pokok struktur atom telah dapat dijadikan modul pembelajaran yang layak digunakan dalam pembelajaran kimia pada materi pokok struktur atom di SMA; (2) Modul pembelajaran berbasis inkuiri terbimbing pada materi pokok struktur atom yang dikembangkan sudah valid menurut validator, karena telah sesuai dengan kurikulum dan konsep yang benar serta sudah menggunakan bahasa yang baik serta modul yang dikembangkan sudah memiliki konsistensi hubungan antar komponen yang baik. Namun masih ada beberapa komponen yang harus disempurnakan; (3) Uji praktikalitas menunjukkan bahwa modul pembelajaran berbasis inkuiri yang dikembangkan sudah praktis digunakan dalam pembelajaran; dan (4) Modul pembelajaran berbasis inkuiri terbimbing pada materi pokok struktur atom sudah efektif digunakan dalam pembelajaran. Hal ini terbukti dari rata-rata nilai tes hasil belajar yang diperoleh siswa berada diatas KKM sekolah untuk bidang studi kimia.

Berdasarkan keterbatasan pengembangan yang diperoleh saat melakukan uji coba di lapangan, dapat disarankan beberapa hal sebagai berikut (1) Bagi guru yang ingin menggunakan modul pembelajaran kimia berbasis inkuiri terbimbing ini dalam pembelajaran di sekolah, disarankan agar benar-benar dapat mengontrol waktu yang disediakan untuk tiap-tiap kegiatan karena ini berhubungan 
Pengembangan Modul Pembelajaran Kimia Materi Pokok Struktur Atomberbasis Inkuiri Terbimbing, Tri Saslina, Mawardi, Latisma Dj

dengan kebiasaan siswa yang masih kurang disiplin dalam belajar. (2) Untuk mengaktifkan semua siswa dalam kegiatan pembelajaran, sebaiknya guru dalam proses pembelajaran mengelompokkan siswa dengan anggota yang tidak terlalu banyak (tidak lebih dari 4 orang).

\section{DAFTAR PUSTAKA}

Alfirahmi, A. (2018). Pengembangan Modul Termokimia Berbasis Inkuiri Terbimbing Terintegrasi Eksperimen untuk Kelas XI SMA/MA. Menara Ilmu, 12(12).

Badlisyah, T., \& Munawwarah, W. (2018).Pengembangan Modul Pembelajaran Kimia Materi Struktur Atom Berbasis Al-Quran di SMAN 1 Aceh Barat Daya. Lantanida Journal, 5(2), 133-144.

Boslaugh, S., \& Watters, P. A. (2008). Statistics in a Nutshell: a Desktop Quick Reference. Sebastopol, CA: O’Reilly Media Inc.

Dahar, R. W. (2011). Teori-teori Belajar dan Pembelajaran. Jakarta: Erlangga.

Hanson, D. M. (2006). Instructor's Guide to Process-Oriented Guided-Inquiry Learning. Lisle, IL: Pacific Crest.

Hanson, D. M. (2005). Designing Process-Oriented Guided-Inquiry Activities. Stony Brook: Pacific Crest

Isworini, I., Sunarno, W., \& Saputro, S. (2015). Pengembangan Modul Pembelajaran Hidrolisis Garam Berbasis Model Inkuiri Terbimbing (Guidedinquiry) untuk Siswa Madrasah Aliyah Kelas XI. Inkuiri, 4(3), 9-20.

Mawantia, T., Fajaroh, F., \& Afandy, D. (2013). Pengembangan Modul Berbasis Inkuiri Terbimbing (Guided Inquiry) pada Pokok Bahasan Reaksi Oksidasi Reduksi untuk Siswa SMK Kelas X. Jurnal Online Universitas Malang, 2(2), 1-8.

Najihah, S. (2014). Pengembangan Model E-Book Interaktif Termodifikasi Majalah pada Materi Struktur Atom (Development Model Of Interactive E-Book Magazine Modification On The Material Atomic Structure). UNESA Journal of Chemical Education, 3(3).

Nurhidayah, R., Irwandi, D., \& Saridewi, N. (2015). Pengembangan Modul Berbasis Inkuiri Terbimbing pada Materi Larutan Elektrolit Dan Non-Elektrolit. EDUSAINS, 7(1), 36-47.

Rochmad. (2011). Model Pengembangan Perangkat Pembelajaran Matematika. Semarang: Unnes.

Sari, R. A., Saputro, S., \& Saputro, A. N. C. (2014). Pengembangan Modul Pembelajaran Kimia Berbasis Blog untuk Materi Struktur Atom dan Sistem Periodik Unsur SMA Kelas XI. Jurnal Pendidikan Kimia, 3(2), 7-15.

Sudjana, N. (2008). Penilaian Hasil Proses Belajar Mengajar. Bandung: Remaja Rosdakarya, Suryosubroto, B. (1983). SistemPembelajarandenganModul. Yogyakarta : PT. Bina Aksara.

Trianto. (2010). Model Pembelajaran Terpadu. Jakarta: Bumi Aksara.

Yerimadesi, Y., Putra, A., \& Ririanti, R. (2017). Efektivitas Penggunaan Modul Larutan Penyangga Berbasis Discovery Learning terhadap Hasil Belajar Siswa Kelas XI MIA SMAN 7 Padang. Jurnal Eksakta Pendidikan (JEP), 1(1), 17-23. 